\title{
JEWS AS LITHUANIAN ARMY SOLDIERS IN 1918-1940 (A QUANTITATIVE ANALYSIS)
}

\author{
Vytautas Jokubauskas, Hektoras Vitkus \\ (Klaipèda University, Institute of Baltic Region History and Archaeology)
}

\begin{abstract}
Even though the subject of military service of Jews in the Lithuanian army in the years 1918 to 1940 is not completely new in historiography, many aspects hitherto covered in academic literature remain relevant to this day. The statistics for Jewish soldiers in the interwar Lithuanian army are without doubt one of those aspects. That is why in this article the aim is not just to identify the scale of participation by the Lithuanian army's Jewish soldiers in the Lithuanian War of Liberation, but also to analyse statistical data relating to Jewish soldiers serving in the interwar Lithuanian army in peacetime.
\end{abstract}

KEYWORDS: Lithuanian army, Jewish soldiers, Lithuanian War of Liberation, conscription, statistics.

\section{Introduction}

Regardless of the fact that attention in Lithuania has recently turned to honouring the memory of Jewish soldiers who died in the Lithuanian War of Liberation in 1919-1920, ${ }^{1}$ the topic of service by Jews (as well as other national-religious and ethnic-confessional groups) in the interwar Lithuanian army has not received a great deal of attention, and nor has a deeper analysis been conducted ${ }^{2}$. In fact, only a handful of works can be distinguished and mentioned. An article by Dov Levin in 2001 touched on the role of Jews in the

${ }^{1}$ 'Jewish Lithuanian soldiers who participated in the Lithuanian War of Liberation honoured in Kaunas', https://kaunas.kasvyksta.lt/2018/o5/30/kultura/kaune-pagerbti-lietuvos-nepriklausomybes-kovose-dalyvave-zydu-tautybes-lieutvos-kariai/ (accessed 201910 5); 'Jews honoured in Kaunas - soldiers with the Lithuanian army', 23 November 2018, https://www.lzb.lt/2018/11/26/kaune-pagerbti-zydai-lietuvos-kariuomenes-kariai/ (accessed 201910 5).

${ }^{2}$ In historiography, the terms used (mostly synonymously) are Lithuanian 'War', 'Wars' and 'Fights' for Liberation. In the interwar press (military press), the concept of 'liberation/independence battles' dominated (see: V. Jokubauskas, 'Periodinio leidinio turinio kiekybinè analizė: 1920-1940 m. Trimito atvejis', in: Istorija, Vol. CXVI, No 4 [2019], pp. 78-108). In this article, we shall use the term Lithuanian War of Liberation. 
1919-1920 Lithuanian War of Liberation. ${ }^{3}$ Works published in Poland and Lithuania by Jonas Vaičenonis analysed aspects of statistics of Jewish soldiers in the Lithuanian army and their terms of service. ${ }^{4}$ The books by Solomon Atamuk ${ }^{5}$ are also worth mentioning, which discussed the number of Jews who served in the Lithuanian army during the interwar period, and the issue of their motivation. Similar issues were raised by Liudas Truska, who noticed that Jews were active participants in the creation of Lithuanian statehood, not only in the political sphere, but at a military level as well. ${ }^{6}$ Aušra Jurevičiūtė has analysed certain aspects of the development and activities of the Union of Lithuanian Jewish Soldiers that participated in the liberation of Lithuania. ${ }^{7}$ Data relevant to this research appears in the publication by Rolandas Gustaitis dedicated to the activities of the Union of Lithuanian Jewish Soldiers who took part in the liberation of Lithuania. ${ }^{8}$ The article by Hektoras Vitkus, one of the co-authors of this research, which analyses the motivation of Jews regarding conscription into the Lithuanian army during the War of Liberation, is also worth noting. ${ }^{9}$ The other co-author of this article, Vytautas

${ }^{3}$ D. Levin, 'Žydai Lietuvos nepriklausomybės kovose', in: Žydų muziejus. Almanachas (Vilnius, 2001), p. 5 o.

${ }^{4}$ J. Vaičenonis, 'Żydzi w wojsku litewskim 1918-1940', in: Od armii komputowej do narodowej (XVI-XX w.), Vol. I (1998), pp. 319-326; J. Vaičenonis, M. Wołos, 'Żydzi na Litwie w łatach 1918-1940', in: Studia i szkice z dziejów w regionie Battyku, eds. Z.H. Nowak, Z. Karpus (Toruń, 1998), pp. 153-165; J. Vaičenonis, 'Prisiekę Adonojo vardu', in: Darbai ir dienos, Vol. 34 (2003), pp. 273-283;

${ }^{5}$ S. Atamukas, Žydai Lietuvoje: XIV-XX amžiai (Vilnius, 199o), pp. 52, 139; idem, Evreiv Litve (Vilnius, 199o), p. 52; idem, Lietuvos žydu kelias: nuo XIV amžiaus iki XXa. pabaigos (Vilnius, 1998), pp. 124, 416.

${ }^{6}$ L. Truska, Lietuviai ir žydai nuo XIX a. pabaigos iki 1941 m. birželio. Antisemitizmo Lietuvoje raida (Vilnius, 2005), pp. 67-68, 70.

${ }^{7}$ A. Jurevičiūtè, Buvusių karių organizacijos ir jų vaidmuo Lietuvos vidaus politikoje 1923-1940 m., PhD thesis (Kaunas, 2009), pp. 79-83, 187-194; A. Jurevičiūtė, 'Žydų karių, dalyvavusių Lietuvos Nepriklausomybės atvadavime, sajunga ir jos veikla Lietuvoje 1933-1940 m.' in: Žydai Pakaunëje, ed. I. Stepukonienè (Kaunas, 2018), pp. 66-123.

${ }^{8}$ R. Gustaitis, 'Soiuz evreiskikh voinov, uchastvovavshikh v bor'be za nezavisimost' Litvy', in: Nauchnye trudy po iudaike. Materialy XX mezhdunarodnoi ezhegodnoi konferentsii po iudaike, Vol. III (Moskva, 2013), pp. 63-69.

${ }^{9}$ H. Vitkus, 'Žydų kariai Lietuvos (lietuvių) Nepriklausomybès (1919-1923 m.) kovose: ką žinome apie jų motyvus?', in: Acta Historica Universitatis Klaipedensis. Creating Modern Nation-States in the Eastern Baltic = Šiuolaikiniu tautiniu valstybiu kūrimas rytiniame Baltijos jūros regione, Vol. XXXVIII, eds. V. Vareikis, S. Pocytė (Klaipèda, 2019), pp. 163-185. 
Jokubauskas, has analysed issues surrounding the service of national minorities, including Jews, in the Lithuanian army through the prism of loyalty and their trustworthiness. ${ }^{10}$ Mindaugas Balkus looked at the education of Jewish soldiers and language use in the interwar Kaunas garrison in his study." A publication compiled by Vilius Kavaliauskas ${ }^{12}$ can also be mentioned, as it reviews issues concerning the military service of Jews in the Lithuanian army during the interwar period. Česlovas Laurinavičius has also touched on the political circumstances behind the involvement of Jews (prompted both internally and externally) in the process of the formation of the Lithuanian army. ${ }^{13}$ Jurgita Šiaučiūnaitė-Verbickienè has turned her attention to reflections in historiography on the role of Jews in the Lithuanian War of Liberation. ${ }^{14}$ One of the most recent works on the topic under analysis has been the study by Eglè Bendikaitė about the activities of Jews from the Panevėžys area during the Lithuanian War of Liberation. ${ }^{15}$ Publications on a similar theme have also appeared in the periodical press ${ }^{16}$ and online media portals. ${ }^{17}$

${ }^{10}$ V. Jokubauskas, Netiesioginis poveikis ir Lietuvos karinis saugumas 1919-1940 m. (Klaipèda, 2019), pp. 95-105, 135-189.

${ }^{11}$ M. Balkus, 'Sociokultūrinis lietuvinimas Kauno iguloje 1919-1940 m.', in: Kauno istorijos metraštis, Vol. 16 (2016), pp. 85-102.

${ }^{12}$ Pažadetoji žemé - Lietuva. Lietuvos žydai kuriant valstybę 1918-1940 m., ed. V. Kavaliauskas (Vilnius, 2013).

${ }^{13}$ Č. Laurinavičius, 'Lietuva - Versalio sistemos provincija ar (ir) pasaulinès revoliucijos forpostas', in: Lietuvos istorija, Vol. 10, Part 1: D. Blažytė-Baužienė, E. Gimžauskas, Č. Laurinavičius, Nepriklausomybe் (1918-1940 m.)(Vilnius, 2013), pp. 99-100, 186.

${ }^{14} \mathrm{~J}$. Šiaučiūnaitė-Verbickienė, 'Žydų ir lietuvių abipusio pažinimo ir kultūrinio bendradarbiavimo atspirtys tarpukario Lietuvoje: priemonès ir rezultatai, in: Abipusis pažinimas: Lietuviu ir žydų kultūriniai saitai, ed. J. Šiaučiūnaitė-Verbickienė (Vilnius, 2010), pp. 27-28.

${ }^{15}$ E. Bendikaitè, 'Lai kalba žygiai ir faktai': Panevėžio krašto žydai Nepriklausomybès kovose', in: Iš Panevėžio praeities: Lietuvos nepriklausomybès gynejjai ir puoselètojai, eds. D. Pilkauskas, Z. Pikelytė (Panevėžys, 2018), pp. 64-83. The topic of Jews who served in the Lithuanian army is developed further in another article by Bendikaite: E. Bendikaitė, 'Už garbę Lietuvos ...' in: Radviliškio kraštas, 1 (2015), pp. 18-23.

${ }^{16} \mathrm{~J}$. Aničas, 'Žydai Lietuvos valstybès atkūrimo darbuose', in: Lietuvos Jeruzalè, 2(40), (1993), p. 2; A. Pociūnas, 'Lietuvos žydai kariai', in: Kauno diena, 2o(246) (1994), p. 18; G. Taicas, 'Pirmosios Lietuvos Respublikos kariuomenès rabinai kapelionai', in: Beigeliu krautuvèle, 2 (2018), pp. 14-16.

${ }^{17}$ D. Januta, 'Lietuvos karžygiai - Lietuvos žydai', http://www.bernardinai.lt/ straipsnis/2010-04-23-donatas-januta-lietuvos-karzygiai-lietuvos-zydai/43923 (ac- 
The first statistical research on Jewish soldiers who served in the army of the First Republic of Lithuania reveals a broad issue. According to the only population census to be conducted during the interwar years in Lithuania, in 1923 the country had a population of 2.17 million, of which 154,000 were Jews (7.15 per cent). Meanwhile, according to data from 1938, the Jewish community in Lithuania consisted of around 170,000 to 180 , ooo people. Thus, during the interwar years, thousands of young Jewish men served in the Lithuanian army, where they received military training and were educated in the spirit of Lithuanian patriotism. The interwar Lithuanian army was based on conscription, which is why over the two decades of its existence, around 280,0oo young men were called up, ${ }^{18}$ while according to General Stasys Raštikis, a former commander of the Lithuanian army (1935-1940), the figure was closer to around 300,000 men. ${ }^{19}$ Thus, around 13 per cent of the Lithuanian population (calculated according to the 1923 census) served in the Lithuanian army, and some were members of national minority groups, including Jews. Some of those who served acquired various professions that were useful in civilian life as well: medics, firefighters, drivers, etc. Through military service, the Lithuanian state not only tried to find a solution to the problem of having a poorly educated population, but also essentially strove to eliminate illiteracy. However, in the case of Jewish soldiers, this issue had its own specific characteristics. Statistical data about military service by Jews in the interwar Lithuanian army makes it possible to show the potential scale of this religious-national group's socialisation and cultural integration into Lithuanian society.

On account of the above research preferences, this study aims to: 1) identify the scale of participation by Jewish soldiers in the Lithuanian War of Liberation; and 2) analyse the statistical data relating to Jewish soldiers serving in the Lithuanian army during peacetime.

cessed 201910 10); A. Lukšas, 'Kitokių lietuvių žygiai', https://luksas.blog/2013/o3/o1/kitokiu-lietuviu-zygiai/ (accessed 20191010 ).

${ }^{18}$ V. Jokubauskas, 'Mažujų kariuomenių' galia ir paramilitarizmas. Tarpukario Lietuvos atvejis (Klaipėda, 2014), p. 108.

${ }^{19} \mathrm{~S}$. Raštikis, 'Lietuvos kariuomenė. Istorija, savanorių žygiai, tarpukario metai, Antrasis pasaulinis karas' (manuscript dated 29 August 1952, USA) in: Karys, 1 (1996), p. 15. 


\section{Statistics concerning the Lithuanian army's Jewish soldiers during the Lithuanian War of Liberation}

The Lithuanian government passed a resolution to establish the armed forces for the country's defence on 23 November 1918, and at the same time, on 29 December, it appealed to the public, inviting volunteers to join the army.$^{20}$ By 15 January 1919, the army had around 3,000 volunteer soldiers, ${ }^{21}$ while during the whole period of the War of Liberation a total of 14,939 individuals joined the army as volunteers ${ }^{22}$ (as of 1 February 1938, 9,995 individuals were recognised as volunteer founders). ${ }^{23}$ Several mobilisations occurred during the War of Liberation, ${ }^{24}$ in which youths born between 1894 and 1901 were conscripted (archival documents available prompt us to make a distinction between three different categories of conscript: a) those included in lists who had to present themselves before a commission; b) those who actually appeared before the new conscript admission commission; and c) those actually admitted to serve in the army. The statistical data for these categories is cardinally varied: this might confuse researchers who may understand and interpret 'conscripts' as those who were accepted for military service.

During the mobilisation of 1919 and 1920, another problem arose: a rather large number of conscripted young Jewish men did not have personal documents (either lost during the Great War [First World War] or non-existent for other reasons), and when new documents were being prepared, they would, as a rule, indicate a year of birth that fell outside the range of the conscription age. In many cases, not even community rabbis could provide registry data (birth registration data) of conscripts, as many of their

${ }^{20}$ 'Pašaukimas savanorių i Krašto apsaugą', in: Vyriausybès žinios, 1 (1918), p. 3.

${ }^{21}$ G. Surgailis, Lietuvos Respublikos kariuomenè 1918-1941 (Vilnius, 1996), p. 10.

${ }^{22}$ K. Uoginius, 'Nepriklausomybė ir savanoriai', in: Karys, 2 (1459) (1970), p. 37.

${ }^{23}$ L. Leknickas, 'Dèl kūrẻjų savanorių skaičiaus', Karo archyvas, Vol. 11 (1939), p. 306.

${ }^{24}$ G. Surgailis, 'The 1919-1920 Lithuanian War of Liberation', in: Wars of Lithuania: A Systemic Quantitative Analysis of Lithuania's War in the Nineteenth and Twentieth Centuries, ed. G. Vitkus (Vilnius, 2014), pp. 149-222. 
archives had disappeared during the deportations of Jews from the western provinces of the Russian Empire (Suwałki, Kovno and Vilno) in the spring of 1915. This is why, in some cases, during mobilisation, Lithuanian army officials would determine the age of Jews according to their appearance, their physical maturity. The Panevėžys Military Commander described the situation in 1921 as follows: 'It's difficult with the Jews. A lot of them are missing birth registration data. The passports they are being issued with now show that they were all born in a year that exempts them from conscription. ${ }^{25}$

There were suspicions of forged personal documents ${ }^{26}$ and false doctors' assessments of the health of Jewish recruits, ${ }^{27}$ and cases of fleeing to another country ${ }^{28}$ (such as Latvia) in order to avoid military service in the Lithuanian army. ${ }^{29}$ The ministry's mobilisation department explained the situation in detail in a note dated 24 September 1919 to the minister of defence Povilas Žadeikis:

... lists of new recruits were being compiled all over Lithuania from registers of births found in churches, but not in a single town did Jews submit their details for these lists. The same response came up everywhere: 'Our birth registry data has been taken away, burned, destroyed.' Nor did we find any German passports, and to this day the municipalities do not have actual lists of their people, and nor do they want to make them. As the recruitment commission started admitting young men based on their external appearance, the Jews grew wary: some started to protest, others suddenly came up with birth registration and all the required documents, which they then presented to the commission; only those whose year of birth fell into the conscription range did not present

${ }^{25}$ P. Pacevičius, Lietuvos kariuomenès dezertyrai 1918-1940 m., MA thesis (Kaunas, 2012), p. 3 o.

${ }^{26}$ New conscript admissions commission chairman for the Skaudvile and Viežaičiai districts, 7 August 1919, Lithuanian Central State Archives (Lietuvos Centrinis Valstybės Archyvas, henceforth henceforth LCVA), col. 929, inv. 5, file 14, p. 35 .

${ }^{27}$ Note from the Mobilisation Section of the Ministry of Defence, 13 August 1919, LCVA, col. 929, inv. 5, file 14, p. 43.

${ }^{28}$ Up to 1 January $1923,4,758$ individuals (i.e. 3.81 per cent of those drafted) were noted as not having returned from abroad to perform military service: news about the course of new conscript admissions as of 1 January 1923, LCVA, col. 929, inv. 5, file 3, p. 2.

${ }^{29}$ Report of the Zapyškis branch of Kaunas District Civil Security, dated 26 July 1919, LCVA, col. 929, inv. 5, file 14, p. 70. 
any documents. There is a very small percentage of Jewish volunteers in the Lithuanian army, more can be found in the German army [there were such cases - author's comment]. ${ }^{30} \mathrm{~A}$ very small percentage reach the front line. An announcement to Jews was made in Panevėžys only because otherwise it would not be possible to recruit a single Jew into the army. There is no evidence of violations of the [Lithuanian] Constitution. The laws express the clear aim of not restricting or violating the national or political rights of Jews, but imply the fulfilment of civil duties. In response to the note-reproach made by the minister of Jewish affairs, instead of a justification, it should be demanded that Jews should not hide birth registration books, that they should not evade conscription, that Lithuania's welfare should be in the hands of all its citizens, that Jews should not make incorrect claims of being 'insulted', and so on. It is time to forget the hate under the Russians, it is time to start creating a common nest for all of us. ${ }^{31}$

The lack of Jewish birth register books was a problem. At the first congress of Lithuanian city and district Military Commanders, held on $20-24$ September 1921, when deliberating the issue of the lack of Jewish conscripts' birth registration data, the possibility of applying penalties to rabbis who avoided submitting these documents was even considered, or forcing them to obtain the data by other devious means. ${ }^{32}$ That is why it can be said that the Lithuanian Jewish community neither created nor imagined the problem of a lack of documents precisely at the time of the mobilisation, but simply exploited the situation that had unfolded at that particular moment.

There were cases of avoiding military service. This is evident from the fact of corruption in the admittance of new recruits by the Vilkaviškis commission in 1929: according to data from the Supreme Headquarters of the Lithuanian Army, the military doctor Captain Kazys Gudelis and the Vilkaviškis district doctor Kudirka accepted 2,00o litas (at the time, one US dollar was equal to ten litas) from Israel Zilber, 1,500 litas from Leiba Rabinovich, 500 litas from Abraham Jankel Frank, and 500 litas from Osher Leib

${ }^{30}$ List of Lithuanian citizens who joined the German army, 25 July 1919, LCVA, col. 929, inv. 5, file 14, pp. 30-3ov.

${ }^{31}$ Note from the Mobilisation Section of the Ministry of Defence, 24 August 1919, LCVA, col. 929, inv. 5 , file 5 , pp. 8-8v.

${ }^{32}$ Pacevičius, Lietuvos kariuomenès dezertyrai 1918-1940 m., p. 3 o. 
Walawicki to deem them unfit for military service. It was also discovered that bribes (the sums of money could not be determined) were paid by Leib Wiezbolowski and Moses Liubocki, who were also relieved from service. All the recruits mentioned were ordered to have another health check, during which Rabinovich tried to fake a spinal disc hernia, even though 'he had just been a healthy and avid football player'. Liubocki went into hiding, and refused to submit evidence or undertake another health check. ${ }^{33}$ It is likely that the case mentioned was an episode from what had become a relatively common phenomenon; nonetheless, it does not allow us to reach any broader conclusions as to the scale of avoidance of military service by Jewish conscripts.

On the other hand, it is likely that some Jews conscripted into the Lithuanian army avoided service not just through disloyalty, but on account of their experience of military service in the Imperial Russian army up to and during the Great War. According to calculations by the historian Semion Goldin, in 1914-1917, no less than 400,000 Jews were mobilised into the Russian army, ${ }^{34}$ some of whom were Jews from the western provinces of the empire. The Russian military leadership did not trust Jewish soldiers, and limited their chances of rising up through the hierarchy to become non-commissioned officers or officers. During the Great War, anti-Jewish prejudice and an anti-Semitic mood prevailed in the Russian army, which had hardly changed since the times of the cantonist system (rounding up Jewish conscripts) of 1827 to 1856 . Understandably, some Jewish veterans who returned to Lithuania after the Great War did not show much enthusiasm to join the Lithuanian army and fight for a country whose political prospects were still rather unclear, while wars were still raging in the region. Thus, according to Poland's military intelligence data, in June 1919, the Belarusian military units in the Lithuanian army consisted of 900 individuals, among whom were around 200 Jews

${ }^{33}$ Report to the Chief Headquarters commander, 9 November 1929, LCVA, col. 4, inv. 1, file 30 , p. 1 .

${ }^{34}$ S. Goldin, Russkaia armiia i evrei 1914-1917 (Moskva, 2018), pp. 14-16. 
(22.22 per cent). ${ }^{35}$ However, according to the historian Gintautas Surgailis, a military mobilisation campaign among the Jewish inhabitants of Grodno to join the Belarusian regiments of the Lithuanian army was conducted in 1919, but Jews did not show much interest in military service. ${ }^{36}$

During the Lithuanian War of Liberation, there were nine Jewish officers fighting on the front line; and of the first group of 89 officers graduating from the Military School in Kaunas, six were Jews. ${ }^{37}$ The almanach Skydas published in 1934 gave the surnames of 36 Jewish volunteer founders. ${ }^{38}$ Twenty Lithuanian Jews were awarded the Vytis Cross for bravery, while Wolf Kagan (Volfas Kaganas), a private in the ist Infantry Regiment of the Lithuanian army, received the award twice (1st class in 1919, 2nd class in 1920). Liba Mednikienè was also among those who were recognised, for collecting and providing intelligence information to the Lithuanian army in 1919-1920, and for actively supporting the riflemen. ${ }^{39}$

In the interwar years, a memorial plaque hung in the Choral Synagogue in Kaunas ${ }^{40}$ with the names of 6o Jewish soldiers who died while serving in the Lithuanian army, ${ }^{41}$ even though the existing data suggests that the list was neither accurate nor complete. According to the list 'Killed soldiers, riflemen, partisans and others missing in action while in service' published in 1937, and archival data, it can be said that not all the surnames of Jews killed during the Lithuanian War of Liberation are included on this memorial plaque. The authors of the study have managed to find the names of several dozen Jewish soldiers who were killed or died and are not mentioned on the plaque, and yet there are some names of individuals who died (some were suicides) in 1918

\footnotetext{
${ }^{35}$ Vaičenonis, 'Prisiekę Adonojo vardu', p. 274.

${ }^{36} \mathrm{G}$. Surgailis, Lietuvos kariuomenes gudu kariniai daliniai 1918-1923 m. (Vilnius, 2020), pp. 34, 87 .

${ }^{37}$ Pažadètoji žemé - Lietuva, p. 199.

${ }^{38}$ Skydas (Kaunas, 1934), pp. 17-18.

${ }^{39}$ Pažadètoji žemé - Lietuva, pp. 233-274.

${ }^{40}$ C. Bargmanas, 'Radinys Kauno sinagogoje', in: Lietuvos aidas, 236 (1995), p. 5 .

${ }^{41}$ Skydas (Kaunas, 1934), p. 6.
} 
near Plunge, when the War of Liberation was not even under way in that area. ${ }^{42}$

Attempts were made during the interwar period to analyse quantitative data relating to Jewish soldiers in the Lithuanian army who participated in the Lithuanian War of Liberation. In 1939, it was announced that of the 9,995 individuals who received official volunteer founder status as of 1 February 1929, 82 were Jews ( 0.82 per cent), 74 professed Judaism, Lithuanians dominated, at 9,768 (97.73 per cent), with the remainder being Germans, Poles, Russians, Belarusians, Latvians and members of other national-confessional or ethnic-religious groups. ${ }^{43}$ So where did the number of 500 Jewish volunteers, which has become accepted in historiography as a fact, come from? As is known, one of the first to mention this number was Atamuk, who did not base his findings on sources from the period in question, but on popular science publications written by other authors, claiming that 'over 5 oo Jewish volunteer soldiers participated in battles for Lithuania's independence. ${ }^{44}$ Truska asserted that, 'according to Jewish historiographical data, of the 10,00o Lithuanian volunteers, there were over 500 , and around 400 Jews in the militarised riflemen's organisation.' ${ }^{45}$ It should be noted that the 5 oo Jewish volunteers figure was already being mentioned in the interwar period. The Jewish 'public thought' weekly Apžvalga, published by the Union of Lithuanian Jewish soldiers, which had participated in reclaiming Lithuania's independence (founded in 1933), ${ }^{46}$ wrote that the number of Jews that took part in the struggles for Lithuanian

\footnotetext{
${ }^{42}$ More thorough research is needed that would encompass all the victims of the mentioned war in order to determine an accurate number of victims: Savanoriu žygiai: Nepriklausomybès karu atsiminimai, ed. P. Ruseckas, Vol. 1 (Kaunas, 1937), pp. 321-349; ibid, Vol. 2 (Kaunas, 1937), pp. 348-350; List of soldiers of the Israelite faith that were killed, died from wounds or disease, who were taken prisoner or went missing in action (1922), LCVA, col. 4, inv. 1, file 99, p. 16.

${ }^{43}$ Leknickas, 'Dèl kūrẻjų savanorių skaičiaus', p. 306.

${ }^{44}$ S. Atamukas, Evreiv Litve (Vilnius, 199o), p. 52.

${ }^{45}$ Truska, Lietuviai ir žydai nuo XIX a. pabaigos iki $1941 \mathrm{~m}$. birželio, p. 67.

${ }^{46}$ In 1939, the Union of Lithuanian Jewish Soldiers, which included those who participated in the liberation of Lithuania, had branches in 49 locations around Lithuania.
} 
independence reached 'several thousand'.47 In data published by this organisation in the 1930s, no fewer than 2,00o Jews participated in the Lithuanian War of Liberation, ${ }^{48}$ of whom around 500 were volunteers. The numbers of Jews who took part in the War of Liberation provided by the Union of Lithuanian Jewish Soldiers, representing participants in the liberation of Lithuania, which were later repeated in historiography, cannot be confirmed in primary sources, and are thus deemed unreliable. ${ }^{49} \mathrm{~A}$ resounding fact is that the union itself had significantly fewer members than this figure: in 1937, it had 2,324 members, and that was the highest number the organisation reached throughout its entire period of activity $^{5^{\circ}}$ (by 1939, the number of members had dropped to 2,o96). Of course, during these two decades, some of the Jewish soldiers who fought in the Lithuanian War of Liberation could already have died, emigrated or simply chosen not to be members of the union for personal reasons.

By the end of 1920, a total of 34,780 recruits had been admitted into the army..$^{51}$ The question remains open as to their national composition (the national composition of volunteer soliders was discussed earlier). The Ministry of Education became interested in the proportion of Jews in the Lithuanian army in the spring of 1921, because at that time there was no 'statistical data about the Lithuanian population based on which the Ministry of Education could, for its own purposes, determine, at least approximately, the ratio between various nationalities', so it requested the national composition of soldiers..$^{2}$ The army began to collect and systematise the required data. According to a summary dated 30 December 1922, it can be said that up to that date, the list of

47 'Žydų karių, d. L.N. a. sajungos skyrių suvažiavo Vilniuje proga', in: Apžvalga, 12(220) (22 April 1940), p. 1.

${ }^{48}$ Pacevičius, Lietuvos kariuomenés dezertyrai 1918-1940 m., p. 3 o.

${ }^{49}$ Atamukas, Žydai Lietuvoje: XIV-XX amžiai, pp. 52, 139; idem, Lietuvos žydu kelias: nuo XIV amžiaus iki XX a. pabaigos, pp. 124, 416; D. Levin, 'Žydai Lietuvos nepriklausomybės kovose', p. 54.

${ }^{5}$ Vaičenonis, 'Prisiekę Adonojo vardu', p. 274.

${ }^{51}$ V. Lesčius, Lietuvos kariuomenè 1918-1920 (Vilnius, 1998), pp. 156-162.

${ }^{52}$ Ministry of Education, Department of Higher Education, 2 May 1921, LCVA, col. 929, inv. 5, file 5, p. 110. 
conscripts admitted into the Lithuanian army (for mobilisation) had 112,531 individuals born between 1896 and 1901 (Table 1), of whom 7,262 were Jews (6.45 per cent). ${ }^{53}$ Not all of them served in the army, because a number of conscripts did not turn up, and some of those who did were deemed unfit for military service due to health conditions or other reasons; in such cases, military service was postponed or cancelled altogether. A total of 55,335 men were admitted into the army, of whom 3,092 were Jews (5.59 per cent), or 2.75 per cent of all the men included on the conscription lists. ${ }^{54}$ This is an accurate figure based on archival documents of Jewish soldiers (born between 1896 and 1901) who served in the Lithuanian army up to 1922 .

Table 1. Men born between 1896 and 1901 drafted on conscription lists of the Lithuanian army up to 3 o December 1922 who presented themselves before the commission and were accepted for military service; in total and Jews.

\begin{tabular}{|c|c|c|c|c|c|c|c|c|c|}
\hline \multirow[t]{2}{*}{$\begin{array}{l}\text { Year of } \\
\text { birth }\end{array}$} & \multicolumn{3}{|c|}{$\begin{array}{l}\text { Included in conscrip- } \\
\text { tion lists }\end{array}$} & \multicolumn{2}{|c|}{$\begin{array}{l}\text { Did not arrive, } \\
\text { or went into } \\
\text { hiding }\end{array}$} & \multicolumn{4}{|c|}{ Accepted for military service } \\
\hline & In total: & Jews & $\%$ & In total: & Jews & $\%$ & In total: & Jews & $\%$ \\
\hline 1896 & 19,268 & 1,142 & 5.93 & $\begin{array}{l}3,533 \\
\end{array}$ & 34 & 6.62 & 8,204 & 445 & 5.42 \\
\hline 1897 & 16,260 & 889 & 5,47 & 2,940 & 13 & 7.24 & 7,622 & 332 & 4.36 \\
\hline 1898 & 16,814 & 927 & 5.51 & 2,820 & 158 & 5.6 & 7,940 & 380 & 4.79 \\
\hline 1899 & 18,685 & 1,028 & 5.5 & 2,838 & 166 & 5.85 & $9,39 \circ$ & 427 & 4.55 \\
\hline 1900 & 20,650 & 1,635 & 7.92 & 2,307 & 248 & 10.75 & 10,683 & 780 & $7 \cdot 3$ \\
\hline 1901 & 20,854 & 1,641 & 7.87 & 3,163 & 343 & 10.84 & 11,496 & 728 & 6.33 \\
\hline Total: & 112,531 & 7,262 & 6.45 & 17,601 & 1,362 & 7.74 & 55,335 & 3,092 & 5.59 \\
\hline
\end{tabular}

Based on data about the number of Jews admitted into the army, 30 December 1922, LCVA, col. 929, inv. 5, file 5, p. 23 .

${ }^{53}$ This is a smaller percentage of Jews than what was shown during the population census of 1923; however, during the Lithuanian War of Liberation and afterwards, Jews did return to Lithuania from regions of the former Russian Empire (following the First World War). The figures might also have been influenced (an increase in the number of Jews on conscription lists) by the Lithuanian army's decision to conscript Jews not according to their documents (year of birth) but according to their physical maturity (appearance).

${ }^{54}$ Data about Jews admitted into the army, 30 December 1922, LCVA, col. 929, inv. 5 , file 5 , p. 23 . 
Another summary report provides data about men born between 1894 and 1902 conscripted (mobilised) into the army up to 1 January 1923. However, there the soldiers are not classified according to nationality. According to that data, the conscription lists had drafted 124,923 individuals, of whom 62,669 (not including volunteers) were actually accepted for military servie, that is, 50.17 per cent of those drafted..$^{55}$ Similar data is given in another summary report about Jewish soldiers: a total of 49.17 per cent of conscripts had been admitted to serve in the army. Thus, of the 62,669 men born between 1894 and 1902, Jews would have made up 3,503 (if the mentioned 5.59 percentage ratio is applied), or 3,435 (applying the 2.75 per cent ratio, the proportion of Jews admitted to serve in the army from those drafted on conscription lists). By narrowing down the chronological boundary to the officially recognised end of the War of Liberation in 1920 (inclusive), the number of Jewish soldiers would be smaller. Up to 1 January 1921, a total of 76,568 men born between 1894 and 1901 were drafted through conscription lists, of whom 33,780 were admitted to military service (44.12 per cent)..$^{6}$ By applying the 5.59 per cent and 2.75 per cent ratios respectively, we arrive at the numbers 1,888 and 2,105 soldiers. In this way, if we add to these numbers the already-mentioned data about volunteers, officers, non-commissioned officers, doctors, war officials and other military contingent data, in the years 1918 to 1920 , the number of Jewish soldiers serving in the Lithuanian army would not be more than 2,500 individuals, and by 1 January 1923, it would have reached around 4,000.

It is worth noting that of the 112,531 men born between 1896 and 1901 and whose names appeared on draft lists, 17,601 (15.64 per cent) did not present themselves to the conscription commission. The names of 7,262 Jews were on these lists, of whom 1,362 (18.76 per cent) did not arrive (they went into hiding). ${ }^{57}$ The Ministry of Defence viewed this situation very sternly, as it 'had an impact

${ }^{55}$ Data about admissions of new conscripts as of 1 January 1923, LCVA, col. 929, inv. 5 , file 3 , p. 2 .

${ }^{56}$ Data about new conscripts admitted into the army, 1 January 1921, ibid., p. 143.

${ }^{57}$ Data about Jewish conscripts admitted into the army, 30 December 1922, LCVA, col. 929, inv. 5 , file 5 , p. 23 . 
on the establishment of the army and set a bad example to those who were starting military service..$^{8}$ Thus, we see a difference of 3.11 percentage points between non-Jews and Jews who avoided military service, and yet it is doubtful whether this difference is good enough grounds for the provision (one that was rather popular in interwar Lithuania) about the exclusive (compared to the general situation) avoidance by Jews to do military service. Let us not forget that declining to submit birth registry details and present oneself before the conscription commission are two different aspects. The non-existence of metric data or its non-inclusion was a circumstance that made it difficult to compile draft lists, which the Lithuanian army tried to resolve by conscripting Jewish youths based on their physical appearance (maturity), as it could not determine their age according to documents. The conscription of Jews (who either did not have or did not submit documents) not according to their year of birth, but based on their physical appearance could have had an impact on the statistics for service in the Lithuanian army during the Lithuanian War of Liberation. A somewhat larger percentage difference emerged between those who presented themselves to the commission and those who were not accepted for military service. The total percentage of this group was 49.17 per cent, of which Jews made up $42.5^{8}$ per cent; however, this is not so much evidence of avoiding the commission as the unsuitability of conscripts for military service, or their non-acceptance for other reasons.

\section{Statistics about Jewish soldiers in the Lithuanian army in $1923-1940$}

In 1923, the Lithuanian army was demobilised and reorganised for peacetime. Throughout the whole interwar period, the army was made up of conscripts rather than voluntary recruits. The term

${ }^{58} \mathrm{Up}$ to the middle of August 1919, 13,046 individuals had been called up, of whom 6,354 (i.e. 48.7 per cent) evaded military service. Avoiding military service was thus widespread, and not only among Jews; this behaviour existed in most of Lithuanian society in 1919. As a result, the army demanded that the Ministry of Internal Affairs implement measures to track down those in hiding: Note from the Mobilisation Section of the Ministry of Defence, 19 August 1919, LCVA, col. 929, inv. 5, file 14, p. 34. 
of service varied from one to three years. ${ }^{59}$ According to the army commander General Stasys Raštikis, during the two decades of the First Republic of Lithuania, around 300,000 young men performed military service, ${ }^{60}$ or, as is mentioned in the introduction, somewhat fewer according to our calculations $(280,000)$. This was a considerable number for a country whose population was barely 2.5 million. On the other hand, the latter indicator suggests that military service in the Lithuanian army touched all social and national groups, including Jews. In 1940, Lithuania had more than 200,000 trained reservists under the age of 45 . If we count that each year Jews made up around 4 to 7 per cent of conscripts, it is likely that in 1940 the reserve forces could have had around 11,000 Jews $^{61}$ who served in the Lithuanian army whose age was below 45. If the 'total indicator' principle is applied, the provision can be raised that in the interwar period, around 15 ,0oo or slightly more Jews could have performed military service in the Lithuanian army, although this hypothetical figure should be verified by conducting further research, which is complicated given the difference in statistical data recorded by the interwar Lithuanian army in certain years (for example, in 1932 conscript statistics according to occupation are given according to districts, ${ }^{62}$ while in 1938 the same data is ordered according to nationality; ${ }^{63}$ a similar situation exists with other data).

Between 1921 and 1934, the proportion of Jewish soldiers in the Lithuanian army ranged between 4 and 7.68 per cent, that is, in different years it was similar or somewhat less than the percentage

${ }^{59}$ V. Jokubauskas, Mažuju kariuomenių' galia ir paramilitarizmas. Tarpukario Lietuvos atvejis (Klaipėda, 2014), pp. 100-110.

${ }^{60}$ Raštikis, 'Lietuvos kariuomenè. Istorija, savanorių žygiai, tarpukario metai, Antrasis pasaulinis karas', p. 15 .

${ }^{61}$ The percentage of Jews among those admitted into the Lithuanian army: 4-7 per cent, average 5.5 per cent, while the number of trained reservists was 200,000. The percentage of those who served can be calculated accordingly, i.e. 5.5 per cent of 280 ,o00-300,ooo.

${ }^{62}$ Record of new conscript admissions for 1932 (those born in 1911), LCVA, col. 929, inv. 5, file 393, pp. 183-193.

${ }^{63}$ Record of new conscript admissions for 1938, LCVA, col. 929, inv. 5, file 529, pp. $1-6$. 
of Jews in Lithuanian society according to the 1923 census. However, based on quantity, the Jewish national group in the Lithuanian army was the second largest after the Lithuanians (Table 2). From 1921 until 1929, of those accepted into the Lithuanian army, Lithuanians made up 88.7 per cent, Jews 5.25 per cent, Poles 1.69 per cent, Russians 2.53 per cent, and young men of other nationalities 1.57 per cent. ${ }^{64}$ By determining the total number of conscripts accepted into the army (Table 3), and the percentage of Jews in this group, it can be calculated that in 1923 around 940 Jews were accepted into the Lithuanian army. In 1928, around 55 o Jews were serving in the Lithuanian army, and in 1934 around 6oo, and so on. Based on the data at hand (the number of conscripts accepted into the army and the percentage of Jews among them), it can be said that between 1923 and 1927, around 3,300 young Jewish men were accepted to serve in the Lithuanian army. During peacetime, the number of Jewish soldiers in the Lithuanian army ranged from several hundred to around a thousand. According to archival source data (despite the fact that in different documents, the number of Jewish soldiers in the same year is not always the same), in $193^{2}$ a total of 10,951 conscripts were admitted for military service, of whom 447 (4.08 per cent) were Jews. ${ }^{6}$ In 1933, 486 Jews were accepted to serve in the army (4.63 per cent of all conscripts). ${ }^{66}$ In 1937, Jews made up 4.4 per cent (555 out of 12,624) of young men (conscripts) admitted to serve in the Lithuanian army. ${ }_{7}$ Of the 12,495 young men who commenced service in 1928, 662 (5.3 per cent) were Jews. ${ }^{68}$ In 1939, 621 Jewish conscripts ( 5.29 per cent) were accepted to serve in the army, out of a total of 11,73 o young men. ${ }^{69}$

${ }^{64}$ A.B., 'Fiziško auklejjimo centralizavimas', in: Kardas, 12(20) (1930), p. 181.

${ }^{6}$ Record of new conscript admissions for 1932 (those born in 1911), LCVA, col. 929, inv. 5 , file 393, p. 193.

${ }^{66} \mathrm{~K}$. Škirpa, 'Exposé Lietuvos ginkluotujų pajègų organizacijos klausimu', in: Karo archyvas, Vol. XXI (2006), p. 336.

${ }^{67}$ Record of new conscript admissions for 1937, LCVA, col. 929, inv. 5, file $5^{28}$, pp. 281-286.

${ }^{68}$ Record of new conscript admissions for 1938, LCVA, col. 929, inv. 5, file 529, pp. 1-6.

${ }^{69}$ Record of new conscript admissions for 1939, LCVA, col. 929, inv. 5, file 557, pp. 1-6. 
Between 1938 and 1940, the Lithuanian army admitted 1,839 Jews for military service..$^{\circ}$ In 1940, it was planned that in the following year, 1941, no fewer than 1,300 Jews would serve in the Lithuanian army. ${ }^{71}$

The statistical data available allows us to construct a collective characterisation of Jewish conscripts in the Lithuanian army. First of all, it faced problems with the education and literacy of its conscripts. In 1921, 8.86 per cent of newly conscripted Jewish soldiers were totally illiterate, 13.84 per cent could read, 28.04 per cent could read and write but had not attended school, 36.34 per cent had completed primary school, and 12.92 per cent had completed education beyond primary level. (Among Lithuanian soldiers, these percentages were $28,18.06,33.22,17.99$ and 2.73 respectively. Among Poles they were 33.72, 20.93, 33.4, 9.30 and 2.91 per cent respectively. Among soliders of other nationalities who had also commenced service, they were 27.25, 20.5, 31.08, 15.54 and 5.63 per cent respectively. $)^{72}$ Between 1921 and 1927, around a quarter of Jewish conscripts (22.5 to 29.2 per cent) were illiterate, while the corresponding data for Lithuanian soldiers varied between 32.4 and 46 per cent. ${ }^{73}$

One of the most critcal problems, from the perspective of the leadership of the Lithuanian army, was the widespread inability among Jewish soldiers to speak the state language. It was said that: 'A majority of Jews, among whom the number of illiterates was smaller than among Lithuanians, do not know how to speak Lithuanian and use Russian.74 According to data from 1921,

${ }^{70}$ By 11 November 1938, 11,870 conscripts had been admitted into the army, of whom 634 were Jews (5.34 per cent); as of 1 May 1939, there were 11,798 conscripts admitted, of whom 610 were Jews (5.17 per cent); as of 1 March 1940, 11,335 conscripts were admitted, of whom 595 were Jews ( 5.25 per cent) (Data about Jews serving in the Lithuanian army, 6 March 1940, LCVA, col. 929, inv. 5, file 652, p. 191).

${ }^{71}$ Army Headquarters Dept. III report, dated 2 June 1940, LCVA, col. 929, inv. 5, file 607, p. 56 .

${ }^{72}$ 'Analfabetizmas naujokų tarpe 1921 m.', in: Mūsų žinynas, Vol. V, No 13 (1923), p. 13 .

${ }^{73}$ The proportion of illiterate Jews in the army: 1921, 22.8 per cent; 1922, 22.5 per cent; 1923, 29.2 per cent; 1924, 22.3 per cent; 1925, 25.1 per cent; 1926, 28.8 per cent; 1927, 27.3 per cent (V. Steponaitis, 'Naujokų èmimo rezultatai 1921-1927 metais', in: Mūsužzinynas, Vol. XV, No 45 (1928), pp. 475, 477).

${ }^{74}$ V. Ter. 'Švietimo reikalu', in: Karys, 34 (170) (25 August 1922), p. 406. 
21.59 per cent of Jews, 49.76 per cent of Poles, and 21.84 per cent of newly conscripted soldiers of other nationalities did not know Lithuanian..$^{75}$ Between 1923 and 1927, the figure ranged from 6.2 to 22 per cent of Jewish young men conscripted into the Lithuanian army who did not know Lithuanian. Compared to the figures among Polish conscripts, this indicator ranged between 25 and 48.7 per cent, even though throughout the whole army, 1.7 to 2.8 per cent of soldiers did not know the Lithuanian state language. ${ }^{76}$ During the spring 1927 conscription, 648 newcomers were accepted into the 1st Lithuanian Grand Duke Gediminas Regiment, including 78 Jews, of whom only five knew Lithuanian. During the autumn conscription, of the 673 who began service, there were 66 Jews, of whom only three knew Lithuanian. Thus, Jews made up 12.04 and 9.81 per cent of newcomers in the regiment, and only 6.41 and 4.55 per cent respectively knew Lithuanian. However, the Lithuanian-language skills of Russian and German conscripts were of a similar level or even worse. Among the Russians, only 10.71 per cent (spring conscription) and ten (autumn conscription) per cent knew Lithuanian (accordingly, only three of the 28 men accepted knew Lithuanian, and one out of the ten admitted in autumn), while among Germans in this regiment in 1927, there were none who knew Lithuanian ( 11 and 17 young men presented themselves, and not a single one knew Lithuanian). ${ }^{77}$ In the spring of 1934, 346 young men joined the 4th Lithuanian King Mindaugas Infantry Regiment, of whom 30 (8.67 per cent) were Jewish, and all of them knew Lithuanian. For comparison: of the 35 (10.1 per cent) Russian newcomers, seven did not know Lithuanian. Thirteen out of 23 (6.65 per cent) German soldiers in the regiment did not know Lithuanian. One Polish soldier appointed to the regiment also did not know Lithuanian. ${ }^{7^{8}}$

${ }^{75}$ M. Balkus, 'Sociokultūrinis lietuvinimas Kauno iguloje 1919-1940 m.', p. 91.

${ }^{76}$ The proportion of Jewish conscripts who did not know Lithuanian: 1923, 18.8 per cent; 1924, 16.7 per cent; 1925, 6.2 per cent; 1926, 22 per cent; 1927, 12.3 per cent (Steponaitis, 'Naujoku ėmimo rezultatai 1921-1927 metais', p. 467).

${ }^{77}$ G. Surgailis, Pirmasis péstininku didžiojo Lietuvos kunigaikščio Gedimino pulkas (Vilnius, 2011), pp. 172-173.

${ }^{78}$ Data about new conscripts entering the 4 th Lithuanian King Mindaugas Infantry Regiment, 4-15 May 1932, LCVA, col. 517, inv. 1, file 236, p. $5^{8 .}$ 
The military collected and systematised valuable data about the education of its conscripts and their social status (Table 4). Most Jewish young men who commenced military service between 1937 and 1939 had a primary education, and compared to the general context, a larger percentage also had a higher education, or had graduated from gymnasiums or pre-gymnasium, while the illiteracy issue had almost been solved; despite this, Russian was still widely used. This fact aroused a negative reaction in the Lithuanian section of the population, ${ }^{79}$ and doubt over the loyalty of this part of the military contingent in the event of war, especially when plans were also being made for partisan-territorial defence alongside a conventional war. ${ }^{80}$ The para-military Lithuanian Riflemen's Union was meant to play a fateful role in the organisation and execution of partisan-territorial defence (after the reforms in the second half of the 193os, the Riflemen's Union came under the command of the Lithuanian army), it was a pro-Lithuanian national defence force (its attitude towards national minorities, including Jews, was rather clear). ${ }^{81}$

Between 1937 and 1939, the social status of Jews who had commenced military service did not stand out in the general context very much. Most Jews came from a craft and trades background. Compared to the general distribution of conscripts according to occupation, there was a greater number of merchants, officials, and school and university students among Jewish soldiers, and

${ }^{79}$ V. Jokubauskas, Netiesioginis poveikis ir Lietuvos karinis saugumas 1919-1940 m., pp. 95-105.

${ }^{80}$ V. Jokubauskas, 'Territorial Defence and Partisan Resistance (Lithuania's Experience)', in: Lithuanian Annual Strategic Review, Vol. 16 (Vilnius, 2018), pp. 331-371.

${ }^{81}$ For more on the organisation's composition and attitudes towards national minorities, see: H. Vitkus, 'Sajungininkai ir (ar) priešai: tautinių mažumų įvaizdžiai Lietuvos šaulių sajungos, Latvijos Aizsargų ir Estijos Kaitseliitų ideologijose', in: Acta Historica Universitatis Klaipedensis, Paramilitarism in the Eastern Baltics, 1918-1940: Cases Studies and Comparisons = Paramilitarizmas Rytu Baltijos regione 1918-1940: atvejo studijos ir lyginimai, Vol. XXVIII, eds. V. Jokubauskas, V. Safronovas, V. Vareikis (Klaipėda, 2014), pp. 223-259; V. Jokubauskas, 'Lietuvos šauliai tarpukariu: lietuviai, katalikai, visuomenès elitas', in: Acta Historica Universitatis Klaipedensis. Paramilitarism in the Eastern Baltics, 1918-1940: Cases Studies and Comparisons = Paramilitarizmas Rytu Baltijos regione 1918-1940: atvejo studijos ir lyginimai, Vol. XXVIII, eds. V. Jokubauskas, V. Safronovas, V. Vareikis (Klaipėda, 2014), pp. 75-102. 
far fewer farmers. This data in effect confirms the stability of the social-economic status of Jews in Lithuania right up to the eve of the Second World War, which has been stated in other research. ${ }^{82}$

Attention should be paid separately to statistical data pertaining to Jewish officers in the Lithuanian army in the period discussed. In terms of the ethnic-confessional aspect, the officer corps in the interwar Lithuanian army was predominantly Lithuanian. In 1925, 95 per cent of officers in the Lithuanian army were Lithuanians, with only 0.3 per cent being Jews (four officers out of the 1,260 in service). In 1934, of the total of 1,301 officers, there was only one person of Jewish descent ( 0.08 per cent of the entire contingent of officers).$^{8_{3}}$ Based on the biographical records of officers, it can be said that there were more Jews among reserve officers, but this was a relatively small percentage. It can be stated that in the period 1918 to 1940, there were several dozen Jewish officers in the Lithuanian army or its reserve forces. During the 22-year period, 42 Jewish officers and no less than ten medics with an officer's rank served in the Lithuanian army. ${ }^{84}$

Table 2. The national composition of soldiers admitted into the Lithuanian army in 1921-1927 who served in 1928-1934 (\%).

\begin{tabular}{|l|l|l|l|l|l|l|l|} 
Year & Lithuanians & Jews & Germans & Poles & Russians & Other \\
\hline Admitted into service & & & & & & \\
\hline 1921 & 86.74 & 5.4 & - & 3.43 & - & 4.43 \\
\hline 1922 & 85.49 & 7.68 & 1.21 & 2.35 & 2.77 & 0.5 \\
\hline 1923 & 86.02 & 7.12 & 2.12 & 1.82 & 2.56 & 0.36 \\
\hline 1924 & 89.31 & 4.47 & 2.64 & 0.95 & 2.15 & 0.48 \\
\hline 1925 & 87.27 & 5.01 & 2.07 & 2.04 & 3.24 & 0.37 \\
\hline 1926 & 87.6 & 5.62 & 1.6 & 1.85 & 3.06 & 0.27 \\
\hline 1927 & 88.7 & 5.25 & 1.57 & 1.69 & 2.59 & 0.2 \\
\hline
\end{tabular}

\footnotetext{
${ }^{82}$ See, for example: G. Vaskela, Tautiniai aspektai Lietuvos ūkio politikoje 1919-1940 metais (Vilnius, 2014), pp. 139-187.

${ }^{83}$ J. Vaičenonis, 'Lietuvos kariuomenès skaičiai 1920-1939 m.', in: Karo archyvas, Vol. XVII (2002), p. 175.

${ }^{84}$ Pažadètoji žemé-Lietuva, pp. 213-232.
} 


\begin{tabular}{|c|c|c|c|c|c|c|}
\hline Year & Lithuanians & Jews & Germans & Poles & Russians & Other \\
\hline \multicolumn{7}{|c|}{ Soldiers who actually served in the army } \\
\hline 1928 & 91.69 & 4.1 & 1.16 & o.39 & 2.31 & 0.35 \\
\hline 1929 & 90.77 & 4.31 & 1.5 & 0.58 & 2.56 & \\
\hline 1930 & 90.75 & $5 \cdot 34$ & 0.88 & 0.21 & 2.56 & \\
\hline 1931 & 90.72 & 4.39 & 1.84 & 0.34 & 2.43 & \\
\hline 1932 & 89.23 & 4.55 & 2.69 & 0.38 & 2.7 & \\
\hline 1933 & 89.41 & 4.36 & 2.59 & 0.43 & 2.83 & \\
\hline 1934 & 89.67 & 4.25 & 2.68 & 0.21 & 2.61 & \\
\hline
\end{tabular}

Based on V. Steponaitis, 'Naujoku èmimo rezultatai 1921-1927 metais', in: Mūsu žinynas, Vol. 15, No 45 (1928), p. 463; J. Vaičenonis, 'Kariuomenè', in: Lietuvos istorija. Nepriklausomybe (1918-1940 m.), Vol. 10, part 1 (Vilnius, 2013), pp. 594-596.

Table 3. The total number of conscripts admitted into the Lithuanian army in $1923^{-1931}$ who served in $1928-1936$.

\begin{tabular}{|c|c|c|c|c|c|}
\hline Year & $\begin{array}{l}\text { Conscripts } \\
\text { admitted }\end{array}$ & Year & $\begin{array}{l}\text { Conscripts } \\
\text { admitted }\end{array}$ & Year & $\begin{array}{l}\text { Conscripts } \\
\text { admitted }\end{array}$ \\
\hline 1923 & 13236 & 1926 & 12113 & 1929 & 8676 * \\
\hline 1924 & 12390 & 1927 & 12864 & 1930 & 10597 \\
\hline 1925 & 9683 & 1928 & 13330 & 1931 & 10119 \\
\hline \multicolumn{6}{|l|}{$\mathrm{XXX}$} \\
\hline Year & In service & Year & In service & Year & In service \\
\hline 1928 & 13456 & 1931 & 12128 & 1934 & 14114 \\
\hline 1929 & 14685 & 1932 & $1385^{8}$ & 1935 & 15215 \\
\hline 1930 & 9498 & 1933 & 13813 & 1936 & 20445 \\
\hline
\end{tabular}

Based on V. Jokubauskas, 'Mažuju kariuomenių' galia ir paramilitarizmas, p. 105; J. Vaičenonis, 'Lietuvos kariuomenès skaičiai 1920-1939 m.', pp. 144-180.

* According to other data, in 1929 the number of conscripted men was 13,388. 


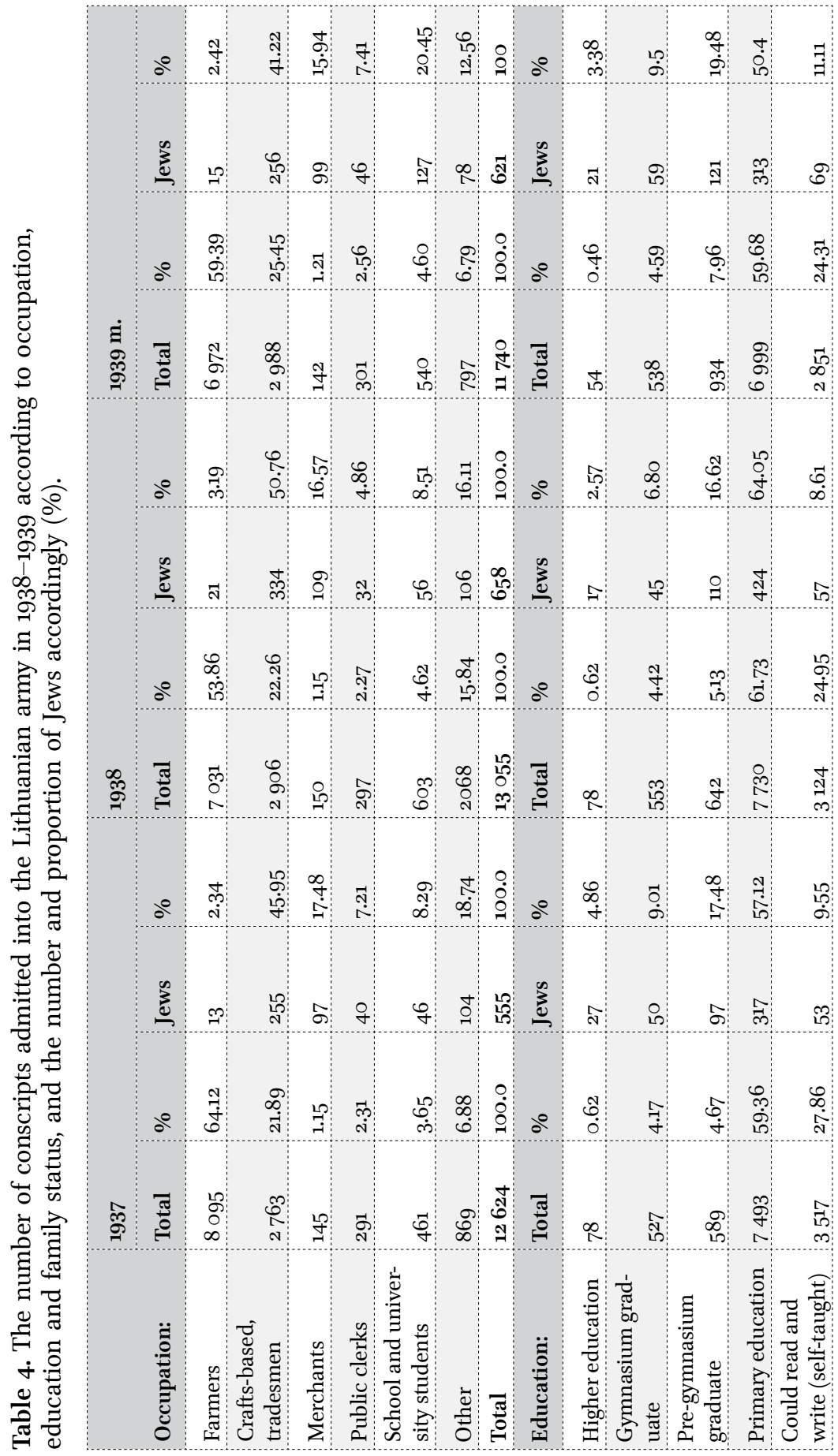




\begin{tabular}{|c|c|c|c|c|c|c|c|c|c|}
\hline$\therefore$ & of & $\stackrel{t}{0}: 8$ & $\alpha^{\circ}$ & 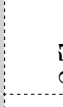 & ơ & $\frac{a}{8}$ & & के & \\
\hline 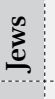 & मे & $+\pi$ & $\stackrel{s}{=0}$ & 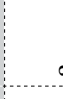 & $\therefore$ & si & & & 8 \\
\hline$\therefore$ & $\stackrel{5}{\rightarrow}$ & $\stackrel{\circ}{9} \stackrel{\circ}{\circ}$ & $\therefore$ & 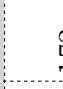 & $\therefore$ & & & ? & \\
\hline 氶 & 요 & สิ & ङू & & & $\begin{array}{l}0 \\
d \\
d\end{array}$ & & & t: \\
\hline$\therefore^{\circ}$ & \%ั & $\stackrel{\circ}{\circ:}$ & $\therefore$ & $\vdots$ & 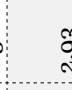 & $\begin{array}{ll}8 \\
\delta\end{array}$ & & : & $:$ \\
\hline 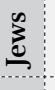 & ه & $\sqrt{8}$ & $\stackrel{s}{E}$ & 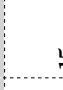 & $\therefore$ & 9 & & & 8 \\
\hline$\therefore$ & 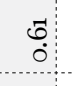 & 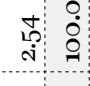 & $0^{\circ}$ & 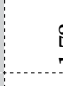 & $\pi$ & 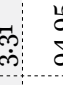 & ? & . & $\dot{:}$ \\
\hline 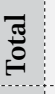 & $\hat{A}$ & 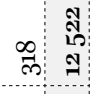 & $\frac{\pi}{g}$ & & 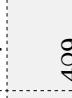 & $\stackrel{8}{8}$ & ? & & : \\
\hline$\therefore^{\circ}$ & $\stackrel{\infty}{0}$ & $\stackrel{0}{\circ}$ & $0^{\circ}$ & 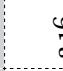 & $\stackrel{8}{\circ}$ & : & ?: & : & : \\
\hline$\stackrel{\stackrel{p}{*}}{\stackrel{w}{*}}$ & - & 용 & 3 & $\therefore$ & $\therefore$ & $\therefore$ & ?: & & 6. \\
\hline$\therefore$ & 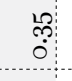 & $\begin{array}{l}\infty \\
\stackrel{0}{0} \\
\dot{0}\end{array}$ & $\therefore$ & $\vdots$ & & 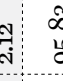 & b. & 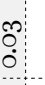 & : \\
\hline స్ّ & F & 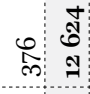 & 氶 & 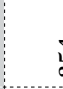 & $\stackrel{\delta}{\sigma}$ & $\stackrel{0}{0}$ & 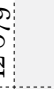 & & 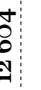 \\
\hline 荾 & 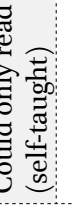 & 量: & $\frac{7}{5}$ & 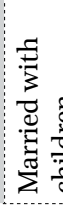 & 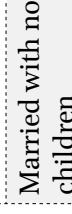 & & 党 & & \\
\hline
\end{tabular}


Table 5. Quantitative data (general and for Jews) regarding young men who were drafted into the Lithuanian army, came before the commission, and presented themselves for military service in 1930-1933 and 1937-1939.

\begin{tabular}{|c|c|c|c|c|c|c|c|c|c|c|c|c|c|}
\hline \multirow[t]{2}{*}{ Year } & \multicolumn{3}{|c|}{$\begin{array}{l}\text { On conscription } \\
\text { lists }\end{array}$} & \multicolumn{3}{|c|}{$\begin{array}{l}\text { Attended the } \\
\text { conscription } \\
\text { commission }\end{array}$} & \multicolumn{2}{|c|}{$\begin{array}{l}\% \text { of those } \\
\text { who presen- } \\
\text { ted them- } \\
\text { selves to the } \\
\text { commission }\end{array}$} & \multicolumn{3}{|c|}{$\begin{array}{l}\text { Accepted for } \\
\text { service }\end{array}$} & \multicolumn{2}{|c|}{$\begin{array}{l}\text { \% of those } \\
\text { accepted } \\
\text { for service } \\
\text { from those } \\
\text { who attend- } \\
\text { ed the com- } \\
\text { mission }\end{array}$} \\
\hline & Total & Jews & $\%$ & Total & Jews & $\%$ & Total & Jews & Total & Jews & $\%$ & Total & Jews \\
\hline 1930 & 22462 & 1512 & 6.73 & 21846 & 1400 & 6.41 & 97.26 & 92.59 & 10202 & 441 & 4.32 & 46.70 & 31.5 \\
\hline 1931 & 32120 & 2300 & 7.16 & 31452 & 2201 & 7.00 & 97.92 & 95.70 & 10573 & 527 & 4.98 & 33.62 & 23.94 \\
\hline 1932 & 32461 & 2232 & 6.88 & 31883 & 2152 & 6.75 & 98.22 & 96.42 & 10951 & 447 & 4.08 & 34.35 & 20.77 \\
\hline 1933 & $305^{21}$ & 2073 & 6.79 & 29824 & 1982 & 6.65 & 97.72 & 95.61 & 11227 & 486 & 4.33 & 37.64 & $24.5^{2}$ \\
\hline 1937 & 21079 & 1282 & 6.08 & $\begin{array}{l}18489 \\
\end{array}$ & $\begin{array}{l}1164 \\
\end{array}$ & 6.30 & 87.71 & 90.80 & 12624 & 555 & 4.40 & 68.28 & 47.68 \\
\hline 1938 & 18471 & 1207 & 6.53 & 15991 & 1044 & 6.53 & $\begin{array}{l}86.57 \\
\end{array}$ & $86.5^{\circ}$ & 12495 & 662 & 5.30 & 78.14 & 63.41 \\
\hline 1939 & 17695 & 1122 & 6.34 & $\begin{array}{l}14745 \\
\end{array}$ & 968 & 6.56 & 83.33 & 86.27 & 11730 & 621 & 5.29 & 79.55 & 64.15 \\
\hline
\end{tabular}

Based on: Autumn 1930 (year of birth 1909) new conscript records, LCVA, col. 929, inv. 5, file 359, pp. 178-186; Record of new conscripts for 1932 (year of birth 1911), LCVA, col. 929, inv. 5, file 393, pp. 183-193; Record of new conscripts for 1933 (year of birth 1912), LCVA, col. 4, inv. 1, file 367, pp. 2-10; Record of new conscripts for 1937, LCVA, col. 929, inv. 5, file 528, pp. 281-286; Record of new conscripts for 1938, LCVA, col. 929, inv. 5, file 529, pp. 1-6; Record of new conscripts for 1939, LCVA, col. 929, inv. 5, file 557, pp. 1-6; Record of new conscripts for 1931 (year of birth 1910), LCVA, col. 4, inv. 1, file 335, pp. 7-9.

Using archival documents from the 1930s, it is possible to determine and compare to what extent Jewish young men performed military service in the Lithuanian army. This can be done by using data from 1930-1933 and 1937-1939 (Table 5). In the first case, this is data submitted prior to the army reforms (in 1929-1930, the conscription age was changed from 20 to 21 , while the term of service was made the same across all sections of the army, 18 months) ${ }^{85}$ In the second, the data comes from seven years (1935-1941) into the Lithuanian army's development and modernisation programme, but before the Lithuanian state had undergone territorial changes. It should be noted that the decline in conscripts, comparing figures from 1931-1933 and 1937-1939, was in part due to the demographic slump that formed on account of the First World War (when birth rates fell by half), which proved to be a serious problem in

\footnotetext{
${ }^{85}$ V. Jokubauskas, 'Mažujų kariuomeniu' galia ir paramilitarizmas, p. 102.
} 
forming military units in the second half of the 193os, when the Lithuanian army sought to expand its structure.

Given the excessive amount of young men of conscription age in $193^{2}$ (compared to what the Lithuanian army needed), service was postponed for a significant number of youths, for 7,856 individuals (24.64 per cent of those who presented themselves to the conscription commission), of whom 568 were Jews (26.39 per cent), while an even larger number were put on reserve or security lists. ${ }^{86}$ In 1937, 2,590 did not present themselves to the conscription commission (408 for legitimate reasons, 105 for illegitimate reasons, 1,457 for unknown reasons, and 620 were taken off draft lists). Accordingly, 118 Jews did not arrive ( 26 for legitimate reasons, 15 for illegitimate reasons, 67 for unknown reasons, and ten were taken off draft lists). Poor health meant that 1,221 individuals were let off military service, of whom 142 were Jews; while another 89 were let off military service because they were members of the clergy or students at religious schools, including 24 Jews. ${ }^{87}$ In 1938, there were 2,48 o draftees who did not present themselves before the conscription commission (488 for legitimate reasons, 38 for illegitimate reasons, 1,518 for unknown reasons, and 436 were taken off draft lists). Of the contingent of draftees mentioned, 163 Jews did not turn up (42 for legitimate reasons, eight for illegitimate reasons, 99 for unknown reasons, and 14 were taken off draft lists). Due to poor health, 1,354 individuals were let off military service, of whom were 132 Jews. Another 111 were also let off because they were members of the clergy or students at religious schools; in this group there were 32 Jews. ${ }^{88}$ Similar data is available for 1939; however, when Lithuania lost the Klaipeda region, the national composition of conscripts in the country changed (the percentage of Germans decreased), and the number of conscripts overall was smaller. Due to poor health, 1,388 individuals were let off serving in the army, of whom 158 were Jews. Of those drafted, there were 88 members of the clergy or religious school students, which included

\footnotetext{
${ }^{86}$ Record of new conscripts for 1932 (born in 1911), LCVA, col. 929, inv. 5, file 393, pp. 183-193.

${ }^{87}$ Record of new conscripts for 1937, LCVA, col. 929, inv. 5, file 528, pp. 281-286.

${ }^{88}$ Record of new conscripts for 1938, LCVA, col. 929, inv. 5, file 529, pp. 1-6.
} 
23 Jews, all of whom were let off military service in the Lithuanian army. ${ }^{89}$ Thus, based on the given data, it can be summarised that the percentage of Jews who did not present themselves to the conscription commission was close to the general percentage of those who did not turn up, while the percentage of Jews admitted for military service was lower (around 10 to 21 per cent in the 1930s) than the average (Diagram 1). That Jews presented themselves is testimony to them not avoiding service, or at least going through the initial checks, while the lower percentage of those deemed fit for service might attest to their relatively poorer physical condition, the greater survival of boys of initially poorer health, and/or a certain institutional attitude. Being let off service due to religious duties or studies also partly had an influence on their acceptance into the army.

Another important aspect revealed in the statistics for the conscription of youths into the Lithuanian army is the percentage of Jews in Lithuanian society in the interwar years. There was only one census, in 1923, during which it was found that Jews made up 7.15 per cent of the country's population. However, it should also be noted that in the 1930s, the percentage of Jews drafted decreased. There is no data to suggest that Jews were ignored at the stage of compiling conscript lists (as these are not equal to actual service in the army). Thus, various hypotheses can be considered. One is that the reduction in the percentage of Jews appearing on conscription lists in the 1930s is indicative of changes in the birth rate in Litvak communities during the First World War. These changes could have been related to the somewhat different (more repressed) ${ }^{9 \circ}$ experience among Jews during the war compared to the rest of society. This hypothesis is confirmed

\footnotetext{
${ }^{89}$ Record of new conscripts for 1939, LCVA, col. 929, inv. 5, file 557, pp. 1-6.

${ }^{90}$ The demographic situation of Jews in Lithuania was severely affected by the violent measures taken against this national-religious group in the Courland, Kovno, Suwalki and Vilno provinces in the spring of 1915 that were sanctioned by Russian military leaders. According to data collected by Rapolas Skipitis, close to 160,000 Jews were driven out of Suwałki, Kovno and part of the Vilno provinces alone, of whom less than half the indicated number could have returned in 1918-1921 (i.e. about 80,000 people). See: R. Skipitis, Nepriklausoma Lietuva statant. Atsiminimai (Chicago, 1961), pp. 265-266.
} 
by 1923 census data according to nationality and age. In the group of children up to and including nine years of age (that is, those born between 1914 and 1923), there were 1.93 per cent fewer Jews than the average in society, ${ }^{91}$ while there could have been even fewer born between 1914 and 1918.

Another possibility is that the fall in the percentage of Jews in Lithuania was influenced by their emigration in the interwar period. Between 1920 and 1940, there were 102,461 people who emigrated, 5,008 of them to Palestine. Between 1928 and 1939, there were 13,898 Jews who emigrated to other countries, or 33.68 per cent of all emigrés (41,268 people). For example, in 1936, 216 men left for Palestine, among whom there were 90 aged from 20 to 39 . In 1938, 44 men emigrated to Palestine, among whom seven were aged from 20 to 24,23 were aged from 25 to 29 , and nine were aged from 30 to $39 .^{92}$ It can be presumed that former soldiers in the Lithuanian army eventually played a part in the Zionist movement in Palestine. The fact that there were former Lithuanian Jewish soldiers among those who emigrated can be confirmed by the experiences of General Vladas Nagevičius in South Africa, when he visited in 1938 and 1939. When he arrived in Durban, he found no Lithuanians, but he was 'approached by Perlingas, a Jewish soldier who had served in the 4th Infantry Regiment, who invited him over to his place. There, he found several dozen Jews who had come from Lithuania at one time or another, who were interested in life in Lithuania. He saw two photographs hanging on the wall at Perlingas' place from his days serving in the Lithuanian army. On other occasions as well when we would come across Lithuanians and Jews who had served in the Lithuanian army, their attachment to the Lithuanian army and interest in how it was doing was noticed. ${ }^{93}$

${ }^{91}$ Lietuvos gyventojai. Pirmojo 1923 m. rugsëjo 17 d. visuotinio gyventojų surašymo duomenys (Kaunas, 1924), p. xlvi.

${ }^{92}$ Lietuvos statistikos metraštis 1938 m. (Kaunas, 1939), Vol. 11, pp. 52-56; G. Vaskela, 'Lietuva 1919-1940 m. http://gevask.dtiltas.lt/GeVask/html/demografija.html (accessed 2009 ०3 24).

${ }_{93}$ 'Apsilankius Pietų Afrikoje', in: Karys, 15 (1035) (1939), p. 478. 
It could be that the percentage of Jewish conscripts is not a reliable indicator determining the percentage of Jews in Lithuanian society, as it only reveals birth rate dynamics and the possible impact of emigration. We can only note that changes to total population figures in Lithuania and to the composition of the population in the interwar period is a particularly sore point, for in official statistics the population of Lithuania is declared ${ }^{94}$ without taking into account the emigration factor. That is why the actual number of inhabitants in the state was smaller. ${ }^{95}$

Diagram 1. The percentage of young men (general and Jews) who presented themselves for military service in the Lithuanian army out of those who were called up and accepted in 1930-1933 and 1937-1939

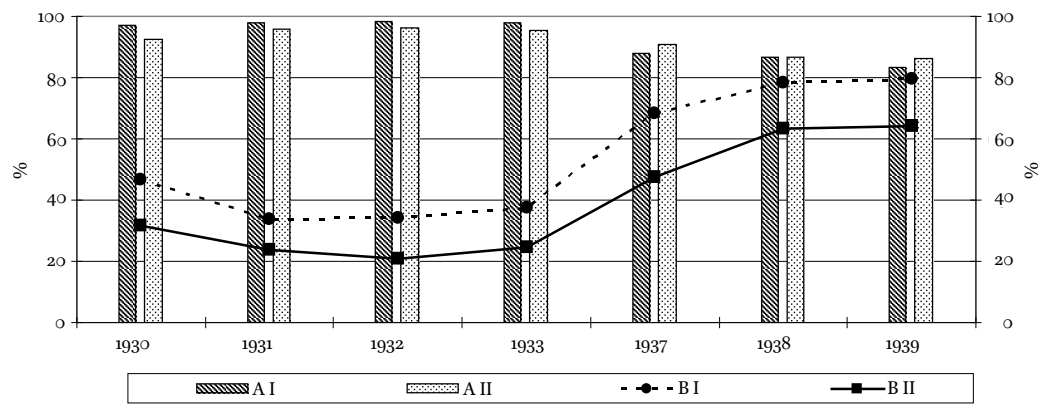

Compiled according to data from Table 5 .

A I - \% of draftees who attended the commission

A II - \% of Jewish draftees who attended the commission

B I - \% of young men accepted for service out of those who attended the commission

B II - \% of Jews accepted for service out of those Jews who attended the commission

\section{Conclusions}

A statistical analysis of the scale of participation by Jewish soldiers in the Lithuanian army during the Lithuanian War of Lib-

${ }^{94}$ In 1932, the population was 2,421,777; in 1937 it was 2,549,668; in 1938 it was $2,575,363$, of whom 153,79 o lived in the Klaipeda region, or not including this territory, 2,421,573 (Lietuvos statistikos metraštis 1938 m., pp. 13, 16).

${ }^{95}$ The Lithuanian population in 1932 was 2,358,311; in 1937 it was 2,475,00o; in 1938 it was 2,498,429 (A. Rimka, 'Lietuvos gyventojai 1936 metais', in: Ekonomika, 2(10) (1937), p. 107; A. Rimka, 'Lietuvos gyventojai 1937 metais', in: Ekonomika, 2(14) (1938), p. 101; A. Jurskis, 'Lietuvos gyventojai 1938 metais', in: Ekonomika, 2(18) (1939), p. 97. 
eration shows that between 1918 and 1920, the number of Jewish soldiers serving in the Lithuanian army did not exceed 2,500. Up to 1 January 1923 , this part of the contingent of Lithuanian army soldiers would have included around 4,00o men. This result in effect confirms the preliminary conclusions reached in interwar Lithuanian historical research, and corrects the provision established in today's historiography to show a larger number of Jewish soldiers who participated in the War of Liberation, at no less than 3,000. The research data analysis also allows us to state that the number of Jews among army volunteer soldiers-founders was also less than 500. On the other hand, the results of the first stage of this research give grounds for claiming that the officially declared and oft-repeated figure for Jewish soldiers who perished in the Lithuanian War of Liberation is inaccurate and is due for verification. The numbers given here reveal the process of the Lithuanian Jewish community's involvement in the founding of the country's army and the 'normality' of their participation in the war, which correlates with the demographic and social potential of Jewish communities in the period after the Great War (First World War) and with the onset of the Lithuanian War of Liberation.

Having analysed statistical data regarding Jewish soldiers in the interwar Lithuanian army in peacetime, it can be stated that up to the occupation in 1940, the number of Jewish soldiers in the country's armed forces ranged from several hundred to around a thousand. For example, between 1923 and 1927, around 3,300 Jews were admitted to serve in the Lithuanian army, around $55^{\circ}$ in 1928, 447 in 1932, 486 in 1933, around 6oo in 1934, and 555 in 1937. Between 1938 and 1940, the number of Jews admitted into the Lithuanian army was 1,839 (in 1940, it was planned that 1,300 Jewish soldiers would perform military service in 1941). The authors of this study maintain that the difference between the number of Jewish soldiers conscripted (and admitted) into military service in 1932-1933 compared to 1937-1939 was due to the demographic slump (birth rates had dropped by half) caused by the Great War (First World War). The assembly of a Lithuanian army contingent consisting of conscripted Jews also faced the problem of emigration by this national-religious group. 
The second stage of the research has determined that the contingent of Jewish soldiers stood out on account of its social characteristics: the illiteracy (or partial literacy) level of Jewish draftees was below that of Lithuanians, some Jewish draftees had a better education and had graduated from gymnasiums or pre-gymnasiums. A significant part of the Lithuanian army's Jewish soldiers were inhabitants of towns or cities (craftsmen, merchants, clerks, and school and university students). These particular social characteristics (especially their widespread use of Russian) could have given grounds for the spread of distrust of the Jewish national group in the Lithuanian army, even though in this regard, the army basically did not differ much from general Lithuanian society. Thus, we can dismiss the idea that the segregation of interwar Lithuanian society along national-religious lines was reflected in the role of Jews in Lithuanian military structures. For example, it can be noted that the statistical analysis allows us to confirm that Jews basically did not see favourable opportunities to pursue a career as an officer in the Lithuanian army. Between 1918 and 1940, there was a total of 42 Jewish officers serving in the Lithuanian army, and no fewer than ten medics with an officer's rank. In relative terms, this is not a high percentage.

Author Details

Vytautas Jokubauskas

Address: Klaipėda University, Institute of Baltic Region History and Archaeology, 84 H. Manto St, Klaipėda, Lithuania

ORCID: oooo-0oo2-5578-4880

Email: pilsotas@yahoo.com

Hektoras Vitkus

Address: Klaipėda University, Institute of Baltic Region History and Archaeology, 84 H. Manto St, Klaipėda, Lithuania

ORCID: oooo-0oo1-5138-3089

Email: hektoras.vitkus@gmail.com 


\section{Bibliography}

A.B. 'Fiziško auklejjimo centralizavimas', in: Kardas, 12 (20) (1930), pp. $180-181$.

'Analfabetizmas naujoku tarpe 1921 m.', in: Mūsų žinynas, Vol. V, No 13 (1923), pp. 130-132.

ANIČAS, Jonas. 'Žydai Lietuvos valstybès atkūrimo darbuose', in: Lietuvos Jeruzale, 2 (1993), p. 2.

'Apsilankius Pietu Afrikoje', in: Karys, 15 (1035) (1939), p. 478.

ATAMUKAS, Solomonas. Evrei v Litve (Vilnius, 1990).

ATAMUKAS, Solomonas. Lietuvos žydu kelias: nuo XIV amžiaus iki $X X$ a. pabaigos (Vilnius, 1998).

ATAMUKAS, Solomonas. Žydai Lietuvoje:XIV-XX amžiai (Vilnius, 199o).

BALKUS, Mindaugas. 'Sociokultūrinis lietuvinimas Kauno iguloje 1919-1940 m.', in: Kauno istorijos metraštis, Vol. 16 (2016), pp. 85-102.

BARGMANAS, Chaimas. 'Radinys Kauno sinagogoje', Lietuvos aidas, 236 (1995), p. 5 .

BENDIKAITĖ, Eglè. "Lai kalba žygiai ir faktai”: Panevėžio krašto žydai Nepriklausomybės kovose', in: Iš Panevėžio praeities: Lietuvos nepriklausomybès gynëjai ir puoselètojai, eds. D. Pilkauskas, Z. Pikelytė (Panevėžys, 2018), pp. 64-83.

BENDIKAITĖ, Eglè. 'Už garbę Lietuvos...', in: Radviliškio kraštas, No 1 (2015), pp. 18-23.

GOLDIN, Semen. Russkaia armiia i evrei 1914-1917 (Moskva, 2018).

GUSTAITIS, Rolandas. 'Soiuz evrejskikh voinov, uchastvovavshikh v bor'be za nezavisimost' Litvy', in: Nauchnye trudy po iudaike. Materialy XX mezhdunarodnoj ezhegodnoj konferencii po iudaike, Vol. III (Moskva, 2013), pp. 63-69.

JANUTA, Donatas. 'Lietuvos karžygiai - Lietuvos žydai', http://www. bernardinai.lt/straipsnis/2010-04-23-donatas-januta-lietuvos-karzygiai-lietuvos-zydai/43923 (accessed 201910 10).

JOKUBAUSKAS, Vytautas. Netiesioginis poveikis ir Lietuvos karinis saugumas 1919-1940 $\mathrm{m}$. (Klaipèda, 2019).

JOKUBAUSKAS, Vytautas. 'Periodinio leidinio turinio kiekybinė analizė: 1920-1940 m. Trimito atvejis', in: Istorija, Vol. CXVI, 4 (2019), pp. 78-108.

JOKUBAUSKAS, Vytautas. 'Territorial Defence and Partisan Resistance (Lithuania's Experience)', in: Lithuanian Annual Strategic Review, Vol. 16 (Vilnius, 2018), pp. 331-371.

JOKUBAUSKAS, Vytautas. 'Lietuvos šauliai tarpukariu: lietuviai, katalikai, visuomenès elitas', in: Acta Historica Universitatis Klaipedensis, Vol. XXVIII: Paramilitarism in the Eastern Baltics, 1918-1940: Cases Studies 
and Comparisons = Paramilitarizmas Rytu Baltijos regione 1918-1940: atvejo studijos ir lyginimai, eds. V. Jokubauskas, V. Safronovas, V. Vareikis (Klaipėda, 2014), pp. 75-102.

JOKUBAUSKAS, Vytautas. 'Mažuju kariuomenių' galia ir paramilitarizmas. Tarpukario Lietuvos atvejis (Klaipėda, 2014).

JUREVIČIŪTĖ, Aušra. Buvusių karių organizacijos ir jų vaidmuo Lietuvos vidaus politikoje 1923-1940 m. $\mathrm{PhD}$ thesis (Kaunas, 2009).

JUREVIČIŪTĖ, Aušra. 'Žydų kariu, dalyvavusių Lietuvos Nepriklausomybės atvadavime, sajunga ir jos veikla Lietuvoje 1933-1940 m.' in: Žydai Pakauneje, ed. I. Stepukonienè (Kaunas, 2018), pp. 66-123.

JURSKIS, A. [Alfonsas]. 'Lietuvos gyventojai 1938 metais', in: Ekonomika, 2(18) (1939), pp. 97-103.

LAURINAVIČIUS, Česlovas. 'Lietuva - Versalio sistemos provincija ar (ir) pasaulinės revoliucijos forpostas', in: Lietuvos istorija, Vol. 10, part 1: D. Blažytė-Baužienė, E. Gimžauskas, Č. Laurinavičius et al., Nepriklausomybe (1918-1940 m.)(Vilnius, 2013), pp. 95-295.

LEKNICKAS, Lionginas. 'Dėl kūrẻjų savanorių skaičiaus', in: Karo archyvas, Vol. 11 (1939), pp. 306-308.

LESČIUS, Vytautas. Lietuvos kariuomené 1918-1920 (Vilnius, 1998).

LEVIN, Dov. 'Žydai Lietuvos nepriklausomybès kovose', in: Žydu muziejus. Almanachas (Vilnius, 2001), pp. 50-77.

Lietuvos statistikos metraštis 1938 m., 11 (Kaunas, 1939).

LUKŠAS, Aras. "Kitokių lietuvių žygiai", https://luksas.blog/2013/o3/o1/ kitokiu-lietuviu-zygiai/ (accessed 201910 10).

PACEVIČIUS, Paulius. Lietuvos kariuomenès dezertyrai 1918-1940 m. MA thesis (Kaunas, 2012).

'Pašaukimas savanorių i Krašto apsaugą', in: Vyriausybės žinios, 1 (1918), p. 3 .

Pažadètoji žemé - Lietuva. Lietuvos žydai kuriant valstybę 1918-1940 m., ed. V. Kavaliauskas (Vilnius, 2013).

POCIŪNAS, Arvydas. 'Lietuvos žydai kariai', in: Kauno diena, 246 (1994), p. 18.

RAŠTIKIS, Stasys. 'Lietuvos kariuomenė. Istorija, savanorių žygiai, tarpukario metai, Antrasis pasaulinis karas' [1952 m. rugpjūčio 29 d. rankraštis, JAV], in: Karys, 1 (1996), p. 15.

RIMKA, Albinas. 'Lietuvos gyventojai 1936 metais', in: Ekonomika, 2(10) (1937), pp. 105-118.

RIMKA, Albinas. 'Lietuvos gyventojai 1937 metais', in: Ekonomika, 2(14) (1938), pp. 101-105.

Savanoriu žygiai: Nepriklausomybès karu atsiminimai, ed. P. Ruseckas, Vols. 1-2 (Kaunas, 1937). 
SKIPITIS, Rapolas. Nepriklausoma Lietuvą statant. Atsiminimai (Chicago, 1961).

Skydas, ed. M. Bregšteinas (Kaunas, 1934).

STEPONAITIS, Vytautas. 'Naujokų ėmimo rezultatai 1921-1927 metais', in: Mūsu žinynas, Vol. XV, No 45 (1928), pp. 447-49o.

SURGAILIS, Gintautas. Lietuvos kariuomenès gudu kariniai daliniai 1918-1923 m. (Vilnius, 2020).

SURGAILIS, Gintautas. Pirmasis pèstininku didžiojo Lietuvos kunigaikščio Gedimino pulkas (Vilnius, 2011).

SURGAILIS, Gintautas. Lietuvos Respublikos kariuomene 1918-1941 (Vilnius, 1996).

SURGAILIS, Gintautas. 'The 1919-1920 Lithuanian War of Liberation', in: Wars of Lithuania: A Systemic Quantitative Anglysis of Lithuania's War in the Nineteenth and Twentieth Centuries, ed. G. Vitkus (Vilnius, 2014), pp. 149-222.

ŠIAUČIŪNAITĖ-VERBICKIENĖ, Jurgita. 'Žydų ir lietuvių abipusio pažinimo ir kultūrinio bendradarbiavimo atspirtys tarpukario Lietuvoje: priemonès ir rezultatai', in: specialusis Lietuvos istorijos studiju leidinys, 8: Abipusis pažinimas: Lietuviu ir žydų kultūriniai saitai, ed. J. Šiaučiūnaitė-Verbickienè (Vilnius, 2010), pp. 15-51.

ŠKIRPA, Kazys. 'Exposé Lietuvos ginkluotujų pajėgų organizacijos klausimu', in: Karo archyvas, Vol. XXI (2006), pp. 336-422.

TAICAS, Geršonas. 'Pirmosios Lietuvos Respublikos kariuomenės rabinai kapelionai', in: Beigeliu krautuvèlè, 2 (2018), pp. 14-16.

TRUSKA, Liudas. Lietuviai ir žydai nuo XIX a. pabaigos iki $1941 \mathrm{~m}$. birželio. Antisemitizmo Lietuvoje raida (Vilnius, 2005).

UOGINIUS, Kalpas. 'Nepriklausomybè ir savanoriai', in: Karys, 2 (1459) (1970), pp. 34-37.

V. Ter. 'Švietimo reikalu', in: Karys, 34 (170) (1922), pp. 405-406.

VAIČENONIS, Jonas. 'Lietuvos kariuomenès skaičiai 1920-1939 m.', in: Karo archyvas, Vol. XVII (2002), pp. 144-180.

VAIČENONIS, Jonas. 'Żydzi w wojsku litewskim 1918-1940', in: $O d$ armii komputowej do narodowej (XVI-XX w.), Vol. I (1998), pp. 319-326.

VAIČENONIS, Jonas, WOŁOS, Mariusz. 'Żydzi na Litwie w łatach 1918-1940', in: Studia i szkice z dziejów w regionie Battyku, eds. Z.H. Nowak, Z. Karpus (Toruń, 1998), pp. 153-165.

VAIČENONIS, Jonas. 'Prisiekę Adonojo vardu', in: Darbai ir dienos, Vol. 34 (2003), pp. 273-283.

VASKELA, Gediminas. Tautiniai aspektai Lietuvos ūkio politikoje 1919-1940 metais (Vilnius, 2014). 
VASKELA, Gediminas. 'Lietuva 1919-1940 m.' http://gevask.dtiltas.lt/ GeVask/html/demografija.html (accessed 2009 o3 24).

VITKUS, Hektoras. 'Sajungininkai ir (ar) priešai: tautinių mažumų įvaizdžiai Lietuvos šaulių sajungos, Latvijos Aizsargų ir Estijos Kaitseliitų ideologijose', in: Acta Historica Universitatis Klaipedensis, Vol. XXVIII: Paramilitarism in the Eastern Baltics, 1918-1940: Cases Studies and Comparisons = Paramilitarizmas Rytu Baltijos regione 1918-1940: atvejo studijos ir lyginimai, eds. V. Jokubauskas, V. Safronovas, V. Vareikis (Klaipėda, 2014), pp. 223-259.

VITKUS, Hektoras. 'Žydų kariai Lietuvos (lietuvių) Nepriklausomybės (1919-1923 m.) kovose: ką žinome apie jų motyvus?', in: Acta Historica Universitatis Klaipedensis, Vol. XXXVIII: Creating Modern Nation-States in the Eastern Baltic = Šiuolaikiniu tautiniu valstybiu kürimas rytiniame Baltijos jüros regione, ed. V. Vareikis, S. Pocytė (Klaipèda, 2019), pp. 163-185. 'Žydų karių, d. L.N. a. sajungos skyrių suvažiavo Vilniuje proga', in: Apžvalga, 12 (220) (1940), p. 1.

\title{
ŽYDAI LIETUVOS KARIUOMENĖS KARIAI 1918-1940 M. (STATISTINE் ANALIZE்)
}

\author{
Santrauka \\ VYTAUTAS JOKUBAUSKAS, HEKTORAS VITKUS
}

\begin{abstract}
Nors pastaruoju metu Lietuvoje atkreiptas dėmesys į žydų karių, žuvusių Lietuvos nepriklausomybės kare 1919-1920 m., atminimo pagerbimą, žydų (taip pat ir kitų tautinių-religinių bei etninių-konfesinių grupių) tarnybos tarpukario Lietuvos kariuomenèje tematikai kol kas neskirta daugiau dėmesio, neatlikta gilesnės analizès. Todèl šiame tyrime siekiama: 1) identifikuoti Lietuvos kariuomenès karių žydų dalyvavimo Nepriklausomybės kare mastą; 2) išanalizuoti taikaus meto tarpukario Lietuvos kariuomenès karių žydų statistinius duomenis. Pagal nurodytas analitines preferencijas sudaryta ir šio tyrimo struktūra: pirmajame straipsnio skyriuje analizuojami Lietuvos kariuomenès karių žydų dalyvavimo Nepriklausomybės kare statistiniais duomenys, antrajame tyrimo skyriuje - Lietuvos kariuomenès kariu žydų statistiniai duomenys taikaus laikotarpio sąlygomis.

Atlikus statistinę Lietuvos kariuomenės karių žydų dalyvavimo Nepriklausomybès kare masto analizę, pavyko nustatyti, kad 1918-1920 m. Lietuvos kariuomenès žydų karių skaičius neviršijo 2500. Iki $1923 \mathrm{~m}$. sausio 1 d. ši Lietuvos kariuomenès karių kontingento dalis būtų apie 400o. Šis tyrimo rezultatas iš esmès patvirtina tarpukario Lietuvos istorinių tyrimų preliminarias išvadas ir koreguoja šiandieninëje istoriografijoje nusistovejjusią nuostatą nurodyti didesnį Nepriklausomybės kare dalyvavusių karių žydų skaičių - ne mažiau 300o. Tyrimo duomenų analizė taip pat leidžia teigti, kad karių savanorių žydų skaičius taip pat buvo mažesnis nei 5 oo.
\end{abstract}


Kita vertus, šio tyrimo pirmojo etapo rezultatas pagrindžia teiginį, kad oficialiai deklaruotas ir istoriografijoje ne kartą kartotas Lietuvos nepriklausomybès kare žuvusių karių žydų skaičius yra netikslus ir verifikuotinas. Pateikti skaičiai rodo Lietuvos žydų bendruomenių î(si)traukimo į šalies kariuomenès kūrimo(si) procesą bei dalyvavimo kare „normalumą”, kuris koreliuoja su žydų bendruomenių demografinėmis ir socialinèmis galimybèmis, kuriomis buvo disponuojama po Didžiojo (Pirmojo) pasaulinio karo ir prasidejus Lietuvos nepriklausomybès karui. Galima teigti, kad tyrimo metu nustatyti karių žydų skaičiai atitiko maksimalų sudètingoje situacijoje atsidūrusių Lietuvos žydų bendruomenių "gyvosios jẻgos" indẻlį, kurį jos galėjo skirti besikuriančios valstybės kariuomenei.

Išanalizavus taikaus meto tarpukario Lietuvos kariuomenės karių žydų statistinius duomenis, konstatuotina, kad iki $1940 \mathrm{~m}$. okupacijos šalies karinėse pajejgose karių žydų skaičius svyravo nuo kelių šimtų iki maždaug tūkstančio. Pavyzdžiui, 1923-1927 m. į Lietuvos kariuomenę buvo priimta tarnauti apie 3300, $1928 \mathrm{~m}$. apie 550, 1932 m. - 447, 1933 m. - 486, 1934 m. - apie 6oo, 1937 m. - 555 žydai. 1938-1940 m. į Lietuvos kariuomenę buvo priimti 1839 žydai (1940 m. planuota, kad 1941 m. tikrają karinę tarnybą atliks 1300 kariai žydai). Tyrimo bendraautoriai daro prielaidą, kad į karinę tarnybą pašauktų (ir priimtų) karių žydų skaičių skirtumas tarp 1932-1933 m. ir 1937-1939 m. buvo nulemtas Didžiojo (Pirmojo) pasaulinio karo sąlygotos demografinès duobès (gimstamumui sumažèjus dvigubai). Lietuvos kariuomenès kontingento komplektavimas šauktiniais žydais neišvengė ir problemų, susijusių su šios tautinès-religinės grupès emigracija. Vis dèlto pagal gausumą žydai Lietuvos kariuomenejje buvo antra tautinė grupè po lietuvių.

Antrajame tyrimo etape nustatyta, kad karių žydų kontingentas išsiskyrẻ savo socialine charakteristika: žydų šauktinių neraštingumo (arba dalinio raštingumo) lygis buvo mažesnis nei lietuvių, nemaža žydų šauktinių dalis turẻjo aukštajį išsilavinimą, buvo baigę gimnazijas arba progimnazijas. Nemažai Lietuvos kariuomenès karių žydų buvo miestų arba miestelių gyventojai (amatininkai, prekybininkai, valdininkai, studentai ir mokiniai). Tokios socialinès ypatybės (ypač rusų kalbos vartojimo paplitimas) galèjo būti pagrindas Lietuvos kariuomenèje tarpti nepasitikẻjimo žydu tautine grupe nuostatoms, nors šiuo požiūriu Lietuvos kariuomenẻ iš esmès nesiskyrè nuo bendro lietuvių visuomenès konteksto. Todèl negalime atmesti, kad tarpukario Lietuvos visuomenès su(si)skirstymas tautiniu-religiniu principu atsispindèjo ir žydu vaidmens Lietuvos kariuomenės struktūrose specifikoje. Pavyzdžiui, galima suprasti, kad statistinė analizė leidžia tvirtinti, kad žydai iš esmès nematė palankių galimybių siekti Lietuvos kariuomenės karininko karjeros. 1918-1940 m. Lietuvos kariuomenėje iš viso tarnavo 42 žydai karininkai ir ne mažiau kaip 10 medikų, turinčių karininkų laipsnius. Palyginti tai nebuvo didelis procentas. 